\title{
Forum
}

\section{Time to move Out of Africa! - A response to Adams and Hulme}

\author{
Ashish Kothari
}

Adams and Hulme (this issue) have provided a useful overview of the current debate regarding community based conservation in Africa. Their conclusion, that the question is not whether conservation should be done with people, but how this should happen, is important, and the points made regarding conservation by communities rather than for communities, and regarding the variety of community conservation (CC) initiatives, are vital. Having said that, however, Adams and Hulme's analysis is incomplete, and I wish here to make some constructive criticisms in order to encourage a more international perspective on this important issue.

The material and cases used are exclusively from Africa, and it should be acknowledged that this is not representative of $\mathrm{CC}$ initiatives across the world. If a global view is taken and, even for Africa, if a full spectrum of initiatives is considered, the following issues would emerge:

1. Although they occasionally mention other organisms, Adams and Hulme more or less concentrate on the 'big animal' definition of wildlife. Many of their 10 arguments detailing circumstances where $\mathrm{CC}$ will not work are dependent on this restricted definition. For instance, their assertion that $\mathrm{CC}$ will not work where the market for wildlife resource is not sustainable, is restricted to examples of tourism and hunting related to large mammals. In many regions of the world, however, CC is dependent on the use of wild plants, smaller animals, and habitats in general. There is now considerable material on such initiatives (Western \& Wright, 1994; White et al., 1994; Stevens, 1997; Gutierrez et al., 2000; Kothari et al., 2000; Ortiz von Halle \& Mazzucchelli, 2000; Roe et al., 2000), and they do not fit neatly into the conclusions reached by Adams and Hulme.

2. Many CC initiatives are generated by cultural factors (e.g. the conservation of sacred spaces), or for ecological functions (e.g. forests as water catchments). Although Adams and Hulme mention this, it is in passing rather than as central theme, and hence the focus is on CC initiatives that are, to quote, '...util-

Ashish Kothari Technical and Policy Core Group, NBSAP, Kalpavriksh, Apartment 5, Shree Dutta Krupa, 908 Deccan Gymkhana, Pune 411004 , India. E-mail: ashish@nda.vsnl.net.in

Manuscript accepted 4 April 2001 itarian, resource-based, revenue generation strategies.' The experience from non-utilitarian CC initiatives is widespread (see references in (1), and also Ramakrishnan et al., 1998; Posey, 1999), and can add important perspectives that are different from those obtained from materialist CC initiatives.

3. The authors acknowledge that 'many' African CC activities are dependent on tourism or safari-hunting, implying that there are others that are not. However, they do not carry out a detailed examination of other resource-based strategies, leading to a limited range of conclusions.

Most of Adams and Hulme's paper concentrates on what could be considered 'externally' initiated projects, and it is therefore weak in developing lessons from efforts initiated by communities themselves. In such efforts the problems and their solutions are self-made, and part of a community's own dynamics and evolution. How these dynamics work out, and how the initiatives evolve when community-led, would provide fascinating and educational learning, but are barely touched upon. Other than material, cultural and aesthetic reasons, a critical incentive for conservation by communities is the sense of empowerment and political control that they derive from it (Kothari et al., 2000; Roe et al., 2000).

Based on the analysis of a somewhat limited range of initiatives, Adams and Hulme stress that community needs and biodiversity preservation objectives cannot be achieved simultaneously, except in rare circumstances. While this is undoubtedly true for many CC initiatives, it is not true for all. For instance, completely protected sacred groves may perform critical ecosystem functions, such as water conservation, that meet a community's development needs. Furthermore, resource reserves in which human activity is severely restricted and regulated by the communities themselves may achieve both conservation and livelihood security. Some such initiatives are mentioned in passing, but justice is not done to them by fully integrating them into the analysis.

For these various reasons I therefore caution against a strong conclusion that there are usually significant trade-offs between development and conservation in $\mathrm{CC}$ initiatives. The exceptions to this supposed rule are many and widespread, especially where habitat and 
ecosystem functions, or low-impact vegetation use, are the prime motivations for community action.

Although Adams and Hulme's Table 1 is an interesting presentation of the conditions for effective CC initiatives, some major conditions are weakly addressed. The first is that of non-financial, material or nonmaterial stakes. Material benefits are listed by them only in the context of 'revenue sharing'. Non-material benefits, although mentioned as the final condition, seem in the context of the article to refer mainly to cultural aspects. But benefits can also be (and in the context of South Asia, for instance, primarily are) subsistence or domestic natural resource uses, and in these cases the condition would be that such benefits have to be adequate, sustainable and secure. Another key condition is the sense of empowerment, which is not only in terms of power-sharing, but often the de facto control that communities take back themselves. Finally, a condition omitted from the table is that of relative equity within the community itself: inequity in decisionmaking or benefit-sharing in a conservation initiative within the community can undermine the effort.

To conclude, Adams and Hulme have undertaken an interesting and useful review of Community Conservation, but have largely restricted themselves to literature from Africa, and mostly to examples of community based hunting and tourism, thus restricting their analysis. An expansion of their work would need to take into consideration the growing literature and experience of CC from around the world (Roe et al., 2000). Most importantly, such a wider analysis would ensure that the international discussion on this vital issue goes beyond the African bias that it has unfortunately had for a long time.

\section{References}

Gutierrez, I., Ortiz, N. \& Imbach, A. (2000) Community Wildlife Management in Central America: A Regional Review. Evaluating
Eden Discussion Paper no. 12. International Institute of Environment and Development, London.

Kothari, A., Pathak, N. \& Vania, F. (2000) Where Communities Care: Community Based Wildlife and Ecosystem Management in South Asia. Kalpavriksh, Pune/Delhi \& International Institute of Environment and Development, London.

Ortiz von Halle, B. \& Mazzucchelli, S. (2000) Community Wildlife Management in South America: A Regional Review. Evaluating Eden Discussion Paper no. 8. International Institute of Environment and Development, London.

Posey, D. (ed.) (1999) Cultural and Spiritual Values of Biodiversity. UNEP, Nairobi and Intermediate Technology Publications, London.

Ramakrishnan, P.S., Saxena, K.G. \& Chandrashekara, U.M. (1998) Conserving the Sacred for Biodiversity Management. UNESCO and Oxford/IBH Publishing, New Delhi.

Roe, D., Mayers, J., Grieg-Gran, M., Kothari, A., Fabricius, C. \& Hughes, R. (2000) Evaluating Eden: Exploring the Myths and Realities of Community-Based Wildlife Management. IIED, London.

Stevens, S. (ed.) (1997) Conservation Through Cultural Survival: Indigenous Peoples and Protected Areas. Island Press, Washington $\mathrm{DC}$.

Western, D. \& Wright, R.M. (eds) (1994) Natural Connections: Perspectives in Community-Based Conservation. Island Press, Washington DC.

White, A.T., Hale, L.Z., Renard, Y. \& Cortesi, L. (eds) (1994) Collaborative and Community-Based Management of Coral Reefs: Lessons from Experience. Kumarian Press, Connecticut.

\section{Biographical sketches}

Ashish Kothari is a founder-member of the Indian environmental action group Kalpavriksh, where he has focused on community-based natural resource management for several years. He has taught at the Indian Institute of Public Administration, and is currently coordinator of the Technical and Policy Core Group that is formulating India's National Biodiversity Strategy and Action Plan. He also heads the IUCN Task Force on Local Communities and Protected Areas. 